one shudder, without officially being told that she had HIV, and who received an injected long-acting contraceptive without her consent or awareness. Hence Farmer exposes how the Western world is not exempt from these pathologies of power. He also describes the life of a Russian prisoner struggling with multidrug-resistant tuberculosis, whose situation was stalemated by a lack of government resources and a stubborn persistence in treating the disease with ineffective drugs.

The first half of the book tells these and other stories on health inequalities - or what Farmer, borrowing from the liberation theology, calls bearing witness. The other half of the text analyzes the foundations of the system leading to these disparities and proposes ways to change it. Farmer reflects on "marketbased medicine," on using diseases such as tuberculosis and HIV as punishment, and on the current disjunction between medical ethics and social justice. Finally, borrowing from anthropological epistemology, he calls for a paradigm shift in health and human rights.

This author also wonders why human rights are the particular domain of lawyers. Farmer strives for human rights equality through direct, communitarian actions as opposed to judicial action. $\mathrm{He}$ refuses to ask for only "basic human rights" for the poor, for they deserve equality in rights; poor people should not be treated as second-class citizens who can be guaranteed only a small part of the care and resources that Westerners have. This is another concept borrowed from liberation theology: "to care preferentially for the poor," to be on their side and to fight with them first and foremost. Like Rudolph Virchow, he sees doctors as "the natural attorneys of the poor." He considers that physicians are privileged because they can take a stand for the oppressed, and that they should do so by rejecting the costeffectiveness approach to health care and the central role of market forces.

Each of these very different books strives to "bear witness." The first is more like an oversized newspaper's special feature on a Nobel Prize-winning organization, while the other is a patchwork of reflections, theories and vivid descriptions of day-to-day health and human rights inequities. Farmer's book goes further, having a strong theoretical base for his work and submitting a working plan to change the world. If Bortolotti's book argues that doctors can't stop genocides, I get the impression that Farmer would reply that they should try ...

\section{Isabelle Leblanc}

First-year Resident

Department of Family Medicine

St. Mary's Hospital

McGill University

Montréal, Que.

\title{
Lifeworks
}

\section{Through the gates}

\section{The Gates}

Christo and Jeanne-Claude

Feb. 12-27, 2005

$\mathrm{T}$ he environmental artists Christo and Jeanne-Claude say there was no message, no symbolism, no purpose to The Gates, Central Park, New York City, 1979-2005, other than to be art.

"We don't define art, we create art," said Jeanne-Claude in an interview at Central Park. "Many journalists and art historians, to make their life easier, they like to have categories and labels. Christo and I believe that labels are very important - for bottles of wine."

This is a jarring admission in a cul$\infty$ ture inundated with expert information, analysis and review as we strive to order our world. This admission is all the more curious with a project like The Gates, which cost \$21 million and attracted global media attention. Surely it must mean something?

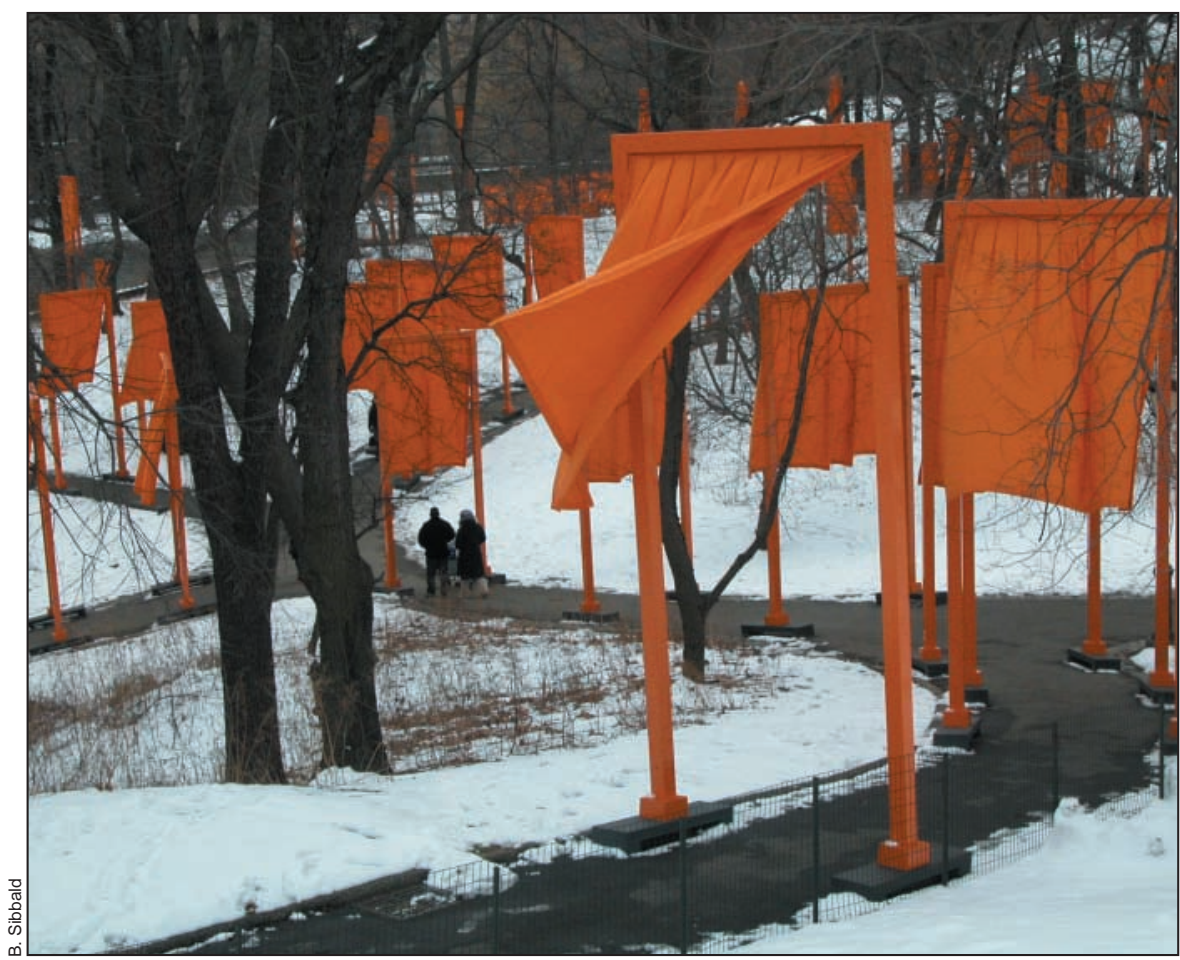


Every interpretation is valid, say the artists, who also admit to wanting to challenge people's notion of art. To look at it another way, their reticence gives viewers the freedom to consider just this notion.

And consider they did. Some said the 7503 16-foot-high gates strung along 23 miles of walkways looked like shower curtains; one reviewer called them a visual one-liner; and the venerable New Yorker chided the artists for saying orange was saffron. It was a huge media phenomenon; some say that's all it was. Parodies materialized online. Critics contrasted it dismissively with the magnitude of previous projects, both wrapped (such as Wrapped Museum of Contemporary Art, Chicago and Wrapped Reichstag, Berlin, 1971-95) and unwrapped (such as Surrounded Islands, Biscayne Bay, Greater Miami, Florida, 1980-83, which featured 6.5 million square feet of pink fabric floating around 11 islands, and the 39kilometre Running Fence, Sonoma and Marin Counties, California, 1972-76). Andy Warhol once remarked that "Art is what you can get away with." Some say that Christo and Jeanne-Claude show just how right he was.

But if the purpose of the work is to attract people to art and stimulate dialogue about it, then The Gates was a resounding success.

Each of the artists' 18 large environmental sculptures has eased into this discourse with a protracted initial period of public dialogue: a 26-year process with The Gates. During this software phase, as the artists call it, the public must be persuaded to allow the work to exist in a given space. "Everything in the world is owned by somebody," Christo said. With The Umbrellas, Fapan-USA, 1984-91, an installation of 3100 two-storey high umbrellas, the artists had to get permission from 479 rice farmers. "We had to go to each of them and drink 6000 cups of green tea," laughs Jeanne-Claude. Wrapped Reichstag, a wrapping in fabric of the German Parliament building, required permission from 37 parties.

Gaining approval for The Gates involved only New York City, but it was no less protracted. The artists' initial application in 1981 generated a 107-page refusal. In the ensuing years the project evolved for practical and aesthetic reasons. The construction materials, height and number of gates all changed; initially there were 1000 gates, then 11000 to 15000 and finally 7503. Saffron (or orange) was selected because the artists felt is was in "perfect harmony with the silver grey of the branches and some of the trunks," and because it offers a great variety of tonalities and hues. "You must have seen it - sometimes they are golden yellow, sometimes deep red, salmon - it keeps changing all the time at every moment of the day according to the sky," said

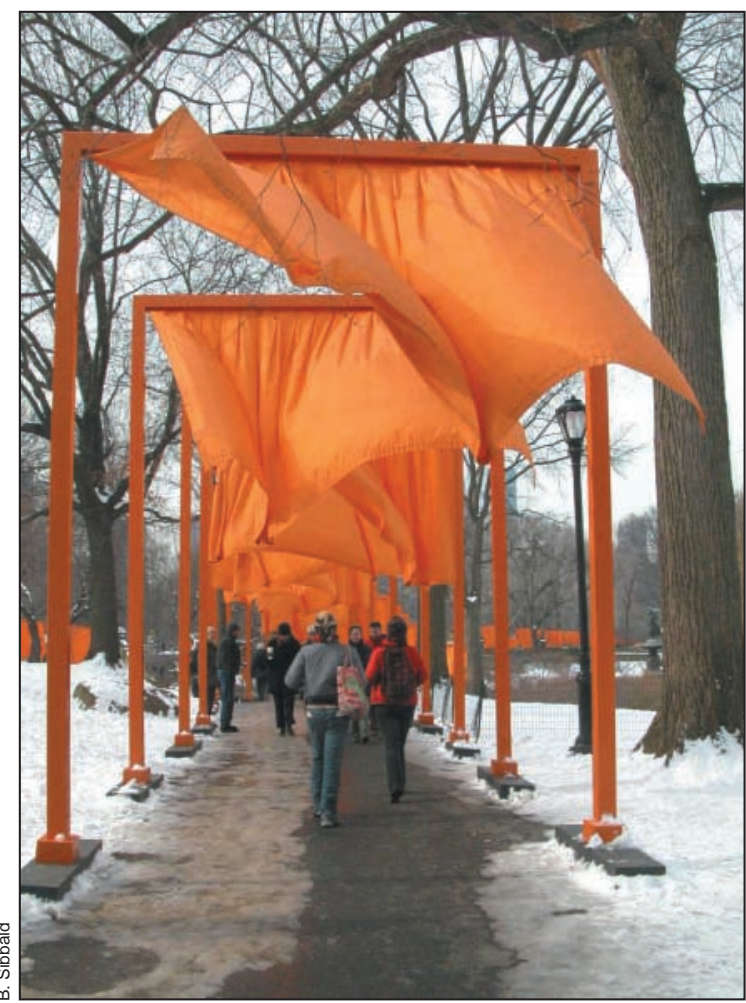
Jeanne-Claude.

While steadfastly refusing to explain this work, Christo allows it is related in some small way to the unrealized plans of Frederick Law Olmsted and Calvert Vaux, the park's designers, to place iron gates at many of the entrances. According to the artists:

The geometric grid pattern of the hundreds of city blocks surrounding Central Park is reflected in the rectangular structure of the commanding and sculptural saffron coloured vinyl poles, while the serpentine design of the walkways and the organic shape of the bare branches of the trees is mirrored in the continuously changing rounded and sensual movements of the free flowing fabric panels moving in the wind.

Initially the artists, who moved from Europe to New York in 1964, sought to wrap various tall buildings in lower Manhattan. But, gradually, their fascination with the city changed focus from the buildings to the people in this, "the most walked city in the world." And the one place they all walked was Central Park. After countless meetings, dinners and discussions, it wasn't until a member of the influential Central Park Conservancy confessed he was a fan, and was subsequently elected Mayor (Michael Bloomberg), that the project got legs.

These public forces, which can't be controlled, give the projects a dramatic element of suspense: will the work get produced when so much depends on outside forces? When so much depends on that most tenuous of things: the public's imagination?

The second phase of dialogue, the hardware phase, occurs when the installation is unveiled - unfurled in this case and people interact with the installation.

On one level, The Gates was a public happening. Passing through the wider gates was reminiscent of a processional; like conquering heroes we marched under celebratory banners. Individually, each gate is unimportant, but taken together, mile after mile, something transformative happens. The Gates lent a sense of well-being and importance to participants. There were smiles all around, a feeling of collaboration, a point of connection. It was a rare experience to walk through a space and hear hundreds of people talking about art. A woman encouraged me to see the view at Harlem Mews. "You'll never forget it," she enthused. Another woman spoke 
of it from the religious view, aligning it with the pearly gates of heaven, the gates of Hades, the four gates of Buddhism and the gates into the shrines of Shinto believers (reinforced by the saffron of the priests' robes), in the context of passing through one world to the next.

"I don't get it," said a young woman, cradling a dachshund inside her blue down-filled jacket. "It makes me smile, but it's not art."

All interpretations are valid.

Each individual gate is like a picture frame, affording a different vista of the surrounding landscape. As we move along in the lower half of the frame, the art changes: the saffron fabric, seven feet above ground, billows in the wind, is static like a theatre curtain or reveals tree shadows and light at play. One emerges at the end of each series of gates to an open, unframed space amidst the silver grey of the naked park, but the gates are never far off: winding and disappearing over knolls, reflecting in ponds, or

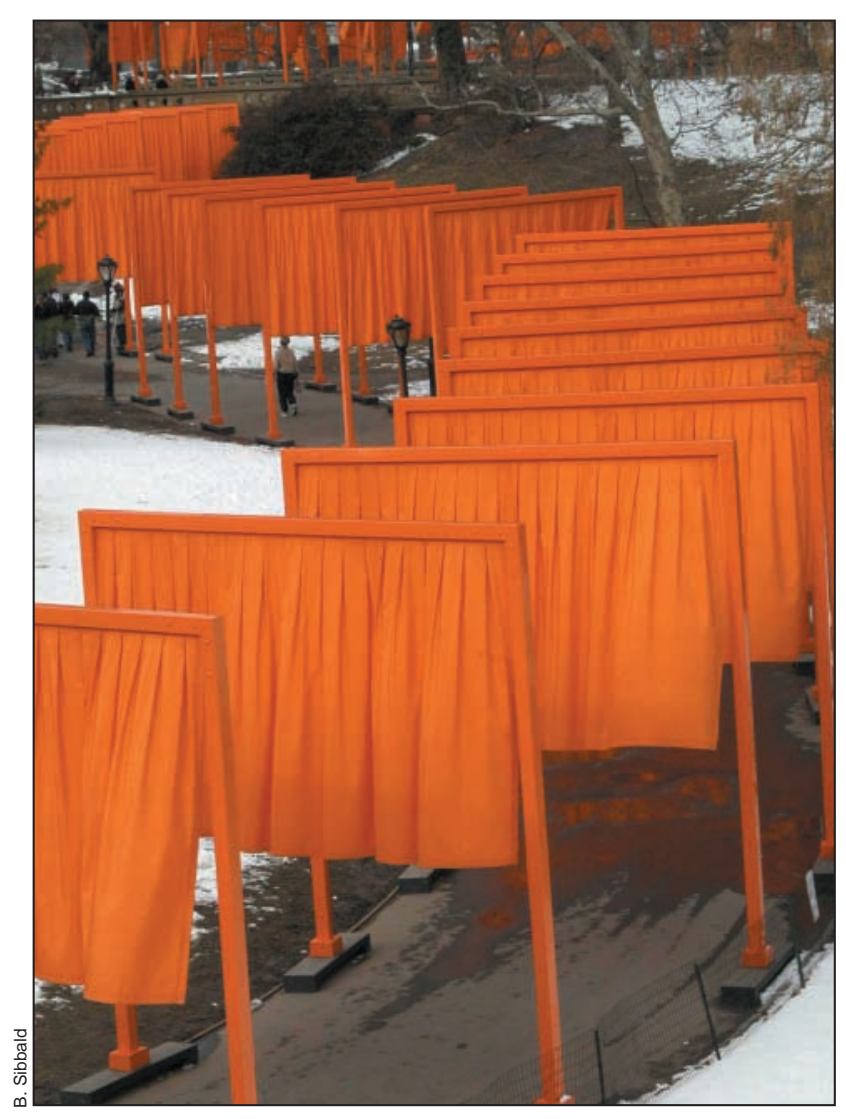

standing sentinel-like along relatively straight roadways. They transform the habitual and our way of seeing. The art and physical space become linked, united through the aesthetics of drawing, painting, sculpture, urban planning and architecture.

The act of walking through the gates is a vital aspect of this transformative process. Gates permit or deny access to space, they delineate property or mark a transition. As one strolls, one crosses a threshold from one space to another, each differentially defined. The repetition of so many gates, so closely spaced signifies a passage of time. Each passing involves a finite moment, a unique view, never to be replicated or reclaimed.

This temporal aspect is mirrored in the temporary nature of the installation itself (their works usually last only two weeks). The Gates stood for a mere 16 days (Feb. 12-27). Normally, art works have a limited number of viewers over a long period of time; here there were extreme numbers (an estimated 4 million) in a very limited period of time. Thus the artists have reversed the habitual temporal and spatial ratio. This sense of urgency builds on the dramatic tension created during the software phase. But, the artists say, the time limitation also endows the works with a sense of tenderness, with feeling usually reserved for other temporary aspects of life, such as childhood. There, then gone.

But, according to Christo, the principal reason the work does not stay is because it is free. "Nobody can buy these projects, nobody can own these projects, nobody can commercialize or sell tickets. This is why our work should go away because it is the enemy of possession, and possession is equal to permanence," he said. "[I]t's all about freedom, even ourselves, we do not own the gates."

"When the projects go away they translate into absolute freedom. They cannot be kept and controlled."

Christo Vladimirov Javacheff was born in Communist Bulgaria in 1935 and studied art under the doctrine of socialist realism. "Like any totalitarian state, Hitler, Stalin, art was the same. And of course I like to go where art could be created freely," said Christo, who escaped to Europe in 1957. "[A]rtists create for themselves. If other people like it, it's a bonus," says JeanneClaude.

"We only do what we want and where we want it, how we want it, and not always when we want it." She smiles.

Despite the staggering price tags of their work, they are self-funded through the sale of collages, drawings and paintings of the projects (The Gates is their first project to fully pay for itself during the course of the installation). Indeed, freedom is the whole point. In the interview, Jeanne-Claude suggested calling this article "A Scream for Freedom."

This freedom extends to the viewer who, unfettered by interpretations, engages in an internal process of dialogue about art. As Christo says: "This project is not involved with talk. It is a real physical space. You need to spend time walking in the cold air — sunny day, rainy day, even snow. It is not necessary to talk." Enough said.

\section{Barbara Sibbald CMA7}

The transcript of the $C M A J$ interview with the artists is posted online at www.cmaj.ca

For information about the artists and their work see christojeanneclaude.net

Christo and Jeanne-Claude: Works from the Weston Collection is on exhibit at the Art Gallery of Ontario until May 15, 2005. 